\title{
Construction of the Ishikawa diagram for the incorporation into employment of graduates of the Ministry of emergency situations of Russia
}

\author{
Vladimir Olegovich Mikryukov ${ }^{*^{*}}$, Sergey Anatolievich Melkov², Andrey Yurievich \\ Lyabakh $^{2}$, Sergey Nikolaevich Ilyushin ${ }^{3}$, and Aleksandra Olegovna Boeva ${ }^{2}$ \\ ${ }^{1}$ Financial University under the Government of the Russian Federation, Department of Sociology, \\ Moscow, Russia \\ ${ }^{2}$ Civil Defense Academy of the Ministry of Emergency Situations of Russia, Department of State and \\ Municipal Administration, Khimki, Russia \\ ${ }^{3}$ State Budgetary Educational Institution of the City of Moscow "School No. 1576", Moscow, Russia
}

\begin{abstract}
The paper presents the results of the author's study of the problem of employment of universities graduates of the Ministry of Emergency Situations (EMERCOM) of Russia for vacant posts in the EMERCOM of Russia. The purpose of the study is to develop a draft "road map" aimed at solving the management problem of insufficient active participation of EMERCOM universities in the employment of graduates for civil service in the EMERCOM of Russia. The authors have used the following methods: traditional document analysis, expert sociological survey in the form of a questionnaire; method of studying statistical data; method for constructing the Kaworu Ishikawa chart. As a result of processing statistical data and experts' answers, the paper presents the author's view of the draft "road map" the implementation of which will solve the problem of effective employment of graduates of EMERCOM universities. The paper presents for the first time the results of the causal relationship between the need for employment of graduates of EMERCOM universities and the low percentage of this employment presented in the form of the Ishikawa chart.
\end{abstract}

Keywords: Ishikawa chart, employment, EMERCOM of Russia, expert survey, road map

\section{Introduction}

In our opinion, there are at least three aspects that determine the relevance of the topic of this study.

Firstly, in modern Russian society, the employment of young experts is the main way not only to organize their own life and self-expression but also to apply the professional knowledge and skills acquired during the educational process.

\footnotetext{
* Corresponding author: mikryukov.v.o@gmail.com
} 
Secondly, the research carried out by the authors is aimed at identifying a management problem that affects the efficiency of the functioning of the student employment system existing in the universities of the EMERCOM of Russia and, subsequently, the effectiveness of the activities of the EMERCOM structural units.

Thirdly, an in-depth study of the chosen topic, as well as the formation of a "road map" with proposals for their implementation at the universities of the EMERCOM of Russia are designed to improve the existing processes of employment for vacant posts in the ministry.

Thus, the management problem that is solved in this study can be formulated as follows: low efficiency of assistance to graduates of universities of the EMERCOM of Russia in the process of employment of students in the EMERCOM structural units.

A consistent solution to this problem can be achieved by posing and solving the following research questions:

1. Is it possible, with the help of the traditional analysis of documents on the employment of graduates of universities of the EMERCOM of Russia, as well as using the internal organizational documents of the Civil Defence Academy of the EMERCOM of Russia, to find out the specificity of employment of graduates and the existing problems?

2. Will it be effective to use methods such as the construction of the Ishikawa chart to develop proposals for solving the problem of low efficiency of assistance to graduates of the Civil Defence Academy of the EMERCOM of Russia in the process of employment students in the structural units of the EMERCOM of Russia?

3. What blocks should the "road map" consist of to solve the problem of employment of graduates of the EMERCOM of Russia?

Thus, the hypothesis of the study sounds like this: assistance of the EMERCOM universities of Russia to students in employment in the structural divisions of this ministry in the early stages will allow the selection of applicants who are most interested in employment for vacant positions in structural bodies among prospective candidates.

Let us turn to the analysis of the research problem. The authors Mikryukov, Melkov and Lyabakh have already analyzed the skills that a university graduate should have for employment in the article [1]. With regard to the application of the Ishikawa chart for various areas of activity, it should be noted that there is a conspicuous lack of articles on its application in Russian. It is possible to name some authors who use the Ishikawa chart: Logunova [2], Gavrilova, Novikova, Petelyak, Nazarova and Agdavletova [3], as well as Voronin, Goryacheva and Kokhova [4], Sheromova and Yanchenko [5]. For this paper, the approach used by Aronov is especially important. He uses it in his scientific article "Modifications of the Ishikawa chart for managing the process of developing regulatory legal acts" [6].

In detail, but in plain language (which is important for young researchers), Ilenkova [7] has conveyed the essence of the Ishikawa chart. We would also note the merits of the Ukrainian researcher Ivanov in popularizing the SWOT analysis and the Ishikawa chart [8, 9]. We also relied on the experience of foreign researchers who use the Ishikawa chart in their articles [10-14].

\section{$2 \quad$ Materials and methods}

The purpose of the author's research is to develop a draft "road map" aimed at solving the management problem of insufficiently active participation of EMERCOM universities in the employment of graduates for civil service in the EMERCOM of Russia. Research objectives directly intersect with research questions, which are indicated in the first section of the paper. 
The authors used the following methods during the study: traditional document analysis, expert sociological survey in the form of a questionnaire; method of studying statistical data; method for constructing the Kaworu Ishikawa chart.

Methodological limitations: the authors have conducted a survey of experts from among the employees of the EMERCOM of Russia. A total of 6 people were interviewed. This is enough to solve the problems of this study. However, in order to scale up and develop recommendations at the level of the EMERCOM of Russia, it is advisable to interview other experts (for example, among the employees of the central office of the EMERCOM of Russia).

\section{$3 \quad$ Results}

The most important current global issue and in the Russian Federation as well is the problem of employment of working-age population. Its importance is determined by the possible positive prospects for the stability of the State. However, the pace and trends of development of modern society require constant monitoring and analysis of the current status. The EMERCOM of Russia has a regulatory framework that regulates the procedure for entering the state civil service in the structural bodies of the department:

1. Federal Law No. 79-FZ of 27.07.2004 "About the State Civil Service of the Russian Federation" [15];

2. Federal Law No. 58-FZ of 27.05.2003 "About the civil service system of the Russian Federation" [16];

3. Decree of the President of the Russian Federation No. 112 of 01.02 .2005 "About the competition for the vacant position of the state civil service of the Russian Federation" [17];

4. Order of EMERCOM of the Russian Federation No. 174 dated 05.04.2012 "About qualification requirements to the professional knowledge and skills necessary for the performance of official duties by federal state civil servants of the central office and territorial bodies of the Ministry of the Russian Federation for Civil Defense, Emergency Situations and Elimination of the consequences of Natural Disasters" (registered in the Ministry of Justice of Russia on May 14, 2012 No. 24140) [18].

Let us analyze the content of each of the above-mentioned documents using the method of traditional document analysis. Federal Law No. 79-FZ of July 27, 2004, fully explains the system of state and municipal service in the Russian Federation highlighting the most important issue for this study on the admission of a candidate to the federal state civil service in the Russian Federation.

Decree of the President of the Russian Federation of 01.02.2005 No. 112 regulates the procedure and competition for filling vacant posts in the state civil service. Considering this document, the authors have revealed that an adult applicant who meets the requirements of an employer can apply for the position. The competition itself is held in two stages.

At the first stage of the competition, information is posted about the search for applicants to fill vacant posts in a state body and basic information about the competition (position, qualification requirements, conditions for civil service, etc.); then an applicant collects some relevant documents At the second stage, a meeting of the recruitment panel takes place, at which applicants are assessed using the documents they have provided; their professional and personal qualities are also estimated.

When considering this decree, the authors revealed an interesting fact regarding the conditions of the second stage of the competition. The meeting can be held only if there are at least two candidates for the vacancy. Although clause 3 of this regulatory legal act does 
not specify the conditions for canceling the competition. If one applicant applies for the post, apparently, the competition should still be held.

The Order of the EMERCOM of Russia No. 174 dated 05.04.2012 gives the right to include the listed requirements in the official regulations. The system of admission to the civil service in the Russian Federation is conditioned by certain professional skills and knowledge that are special for each of the groups of relevant posts.

Thus, having analyzed the most important regulatory legal acts for the research using the traditional document analysis method designed to regulate the process of employment of applicants for vacancies of the federal state civil service in the structural bodies of the EMERCOM of Russia, the authors have drawn the following conclusions:

- Normative legal acts have the main provisions governing the process of employment of applicants in the structural bodies of the EMERCOM of Russia are presented;

- The analyzed regulatory legal acts prescribe the basic professional knowledge and skills that are necessary for passing the civil service for different categories of job groups;

- For the purposes of this study, the procedure presented in the regulatory legal acts data for holding a competition to fill a vacancy is interesting.

From the data available about the labor market's need for experts for the EMERCOM of Russia departments, the authors conclude that the structural divisions have a significant staffing reserve, which can be used by any graduate of EMERCOM universities. Having considered some vacancies for the employment of students, which are offered by the personnel structures of the EMERCOM of Russia, the authors have identified some features of the labor market in the conditions of seeking posts in the structural divisions of the EMERCOM of Russia. They are presented in table 1.

Table 1. Features of the labor market for full-time students of the Civil Defence Academy in the context of seeking vacancies in the EMERCOM of Russia. Source: compiled by the authors.

The identified
feature of the Substantiation of the identified features of the labor market for
labor market for applicants to the structure of the EMERCOM of Russia
job seekers

There is no association with a specific location. Vacancies in the structural

Geography bodies of the EMERCOM of Russia are open in every region of the Russian Federation. Most vacancies for civilian experts in the humanitarian and engineering fields can be found outside the Central Federal District.

This feature is due to the fact that for applicants for filling vacancies in the

Group of posts structural divisions of the EMERCOM of Russia, a group of positions not higher than the main group of positions are offered.

\begin{tabular}{ll}
\hline & $\begin{array}{l}\text { Most of the posts (discarding territorial linkages) have a technical nature in } \\
\text { the conditions of training "State and Municipal Administration" (hereinafter } \\
\text { Technical experts } \\
\text { employable (meaning the EMERCOM of Russia) than graduates of } \\
\text { engineering training areas. }\end{array}$ \\
\hline $\begin{array}{l}\text { Conditions for } \\
\text { filling vacant posts }\end{array}$ & $\begin{array}{l}\text { The procedure for employment in the structural divisions of the EMERCOM } \\
\text { of Russia is a long and rather complicated procedure for holding a } \\
\text { competition for a vacant post. }\end{array}$ \\
\hline
\end{tabular}

In the context of the dynamic socio-economic conditions in the country, the

Labor potential low percentage of graduates employed in the structural units of the EMERCOM of Russia is caused by a lack of their work experience or by their unwillingness to work in that ministry at all. 
Therefore, we can conclude from the analysis of Table 1 that employment in the specialized structures of the EMERCOM of Russia occurs with significant difficulties. In addition to these factors, job market in specialized organizations lays down strict disciplinary requirements, which also affect the motivation of an applicant. Accordingly, quite often, after graduating from the EMERCOM universities prospective applicants choose employment in commercial organizations where an employer offers flexible working arrangements and the employment process itself does not take as much time as in the structural units of the EMERCOM of Russia.

Having considered the system of employment in the Department for the Eastern Administrative District of the Directorate General of the EMERCOM of Russia in Moscow, the authors consider it appropriate to turn to the analysis of statistical data taken from official sources of one of the leading universities - the Civil Defence Academy of the EMERCOM of Russia. If we consider the overall picture of the engineering and humanities faculties of the EMERCOM of Russia (civilian students study at these faculties), then the total number of graduates from 2017 to 2019 is about 254 people [19]. Of all the graduates (254 people), only 49 people are employed in the EMERCOM of Russia, while there are a total of about 64 unemployed or employed in non-governmental organizations (36 are employed in non-governmental organizations; 28 are not employed at all) [19]. General information on the employment of full-time students at the expense of the federal budget in 2017, 2018, and 2019 from the Civil Defence Academy is shown in Figure 1.

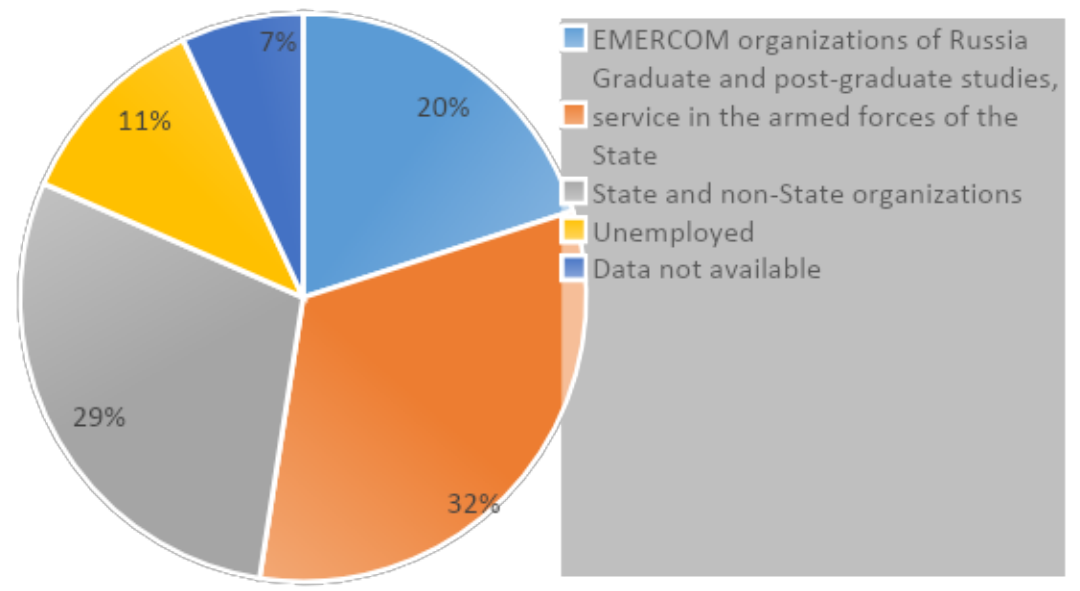

Fig. 1. General information on the employment of students enrolled in full-time education at the expense of the federal budget in 2017, 2018, 2019, graduated from the Civil Defence Academy of the EMERCOM of Russia. Source: compiled by the authors.

Figure 1 shows that the share of employed graduates, taking into account employment in governmental and non-governmental organizations, is $32 \%$ (71 people) of the total number of all experts graduated from the Academy (254 people). At the same time, the share of graduates employed by the EMERCOM of Russia is $20 \%$ of the total number of graduates (49 people), which is even less in comparison with the percentage of those applicants who got government and non-government jobs. We can state the unstable dynamics of the employment rates of graduates of the Civil Defence Academy of the EMERCOM of Russia and a small percentage of employment of graduates of this university. It indicates the ineffectiveness of meeting the goals and objectives of the 
Development Strategy of the Civil Defence Academy of the EMERCOM of Russia until 2030, which means the management problem of low efficiency of assistance to graduates of the Civil Defence Academy of the EMERCOM of Russia in the process of employment students in the structural divisions of the EMERCOM of Russia.

According to the author's intention, in order to solve this problem, it is necessary to construct a cause-and-effect diagram or an Ishikawa chart [20]. To do this, the authors have conducted an additional expert survey in the form of a questionnaire. The experts were 6 managers of the Department for the Eastern Administrative District of the Directorate General of the EMERCOM of Russia in Moscow. The introduction of the cause-and-effect diagram is undertaken with the aim of graphic display the relationship between the problem being solved and the reasons that influence its occurrence. The Ishikawa chart itself is constructed in four stages. As a result, it looks very impressive (see Figure 2). 


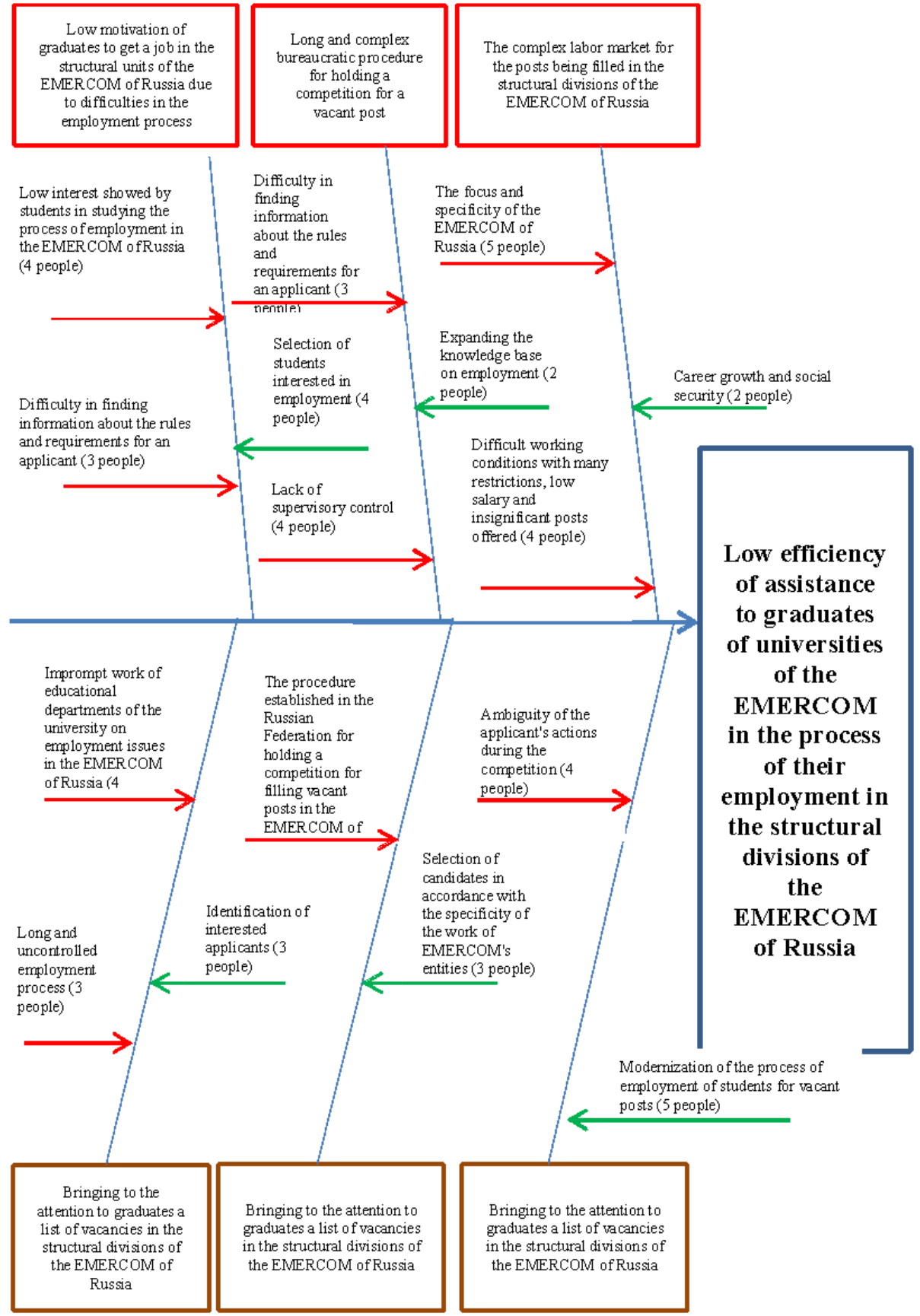

Fig. 2. The result of the graphical analysis on the research problem is the Ishikawa chart. Source: compiled by the authors.

The Expert Group has also identified 3 reasons that, in their opinion, most affect the problem, namely:

- bringing to the attention to graduates a list of vacancies in the structural divisions of the EMERCOM of Russia; 
- independent solution of problematic issues by graduates when applying for employment in the structural bodies of the EMERCOM of Russia;

- visible activity of universities of the EMERCOM of Russia in the process of employment of graduates.

Next, the experts were asked to determine the significance of factors affecting the employment of graduates of the EMERCOM of Russia in this Ministry. As a result of the calculation, it turned out that the most important factors are a long and complex bureaucratic procedure for holding a competition for a vacant post, low interest of students themselves in studying the employment process, selection of candidates in accordance with the specificity of work in the structural bodies of the EMERCOM of Russia, and modernization of the process of student employment for vacant post.

\section{Discussion}

Having constructed the Ishikawa chart, based on the data of an expert survey, the authors have justified the key issues that affect the solution of the problem of employment of graduates of the EMERCOM of Russia in this ministry.

We believe that the measures proposed in the chart (see Figure 2) should be taken to fruition, that is, to propose specific management actions that will be able to optimize employment processes making them more effective. We accordingly get a "road map" to solve the problem of employment of graduates of the EMERCOM of Russia for vacant posts in this ministry. The proposals set out below were also verified during an expert survey (the survey of the expert group was conducted in mid-February 2021, 5 people were also interviewed - experts of the personnel bodies of the EMERCOM of Russia). Therefore, the authors consider it necessary to propose the following activities:

1. Creation of a structural unit in each university of the EMERCOM of Russia, where students are enrolled on a paid basis of the organizational unit responsible for coordinating the employment of graduates in the structural bodies of the EMERCOM of Russia;

2. Reforming of the chapter on employment on the official website of the universities of the EMERCOM of Russia, so that graduates always have access to an updated database of vacant posts and can easily get this information;

3. Organization of mentorship activities in the universities of the EMERCOM of Russia (in the structural divisions of the EMERCOM of Russia (Directorate Generals among the constituent entities of the Russian Federation, rescue centers of the EMERCOM of Russia, etc.). You should have a person who would be in permanent contact with the student council of the University of the EMERCOM of Russia and would explain the specificity of employment and the algorithm of rapid selection for vacant posts;

4. Add a new introductory discipline, where students will be able to study in detail the entire process of employment in the EMERCOM of Russia;

5. Use of means and methods of informing students about the prospects of work/service in the EMERCOM of Russia (social videos about the professions of the EMERCOM of Russia, posters, trainings, master classes of the best professionals of the EMERCOM of Russia, etc.).

\section{Conclusion}

In conclusion, we note that based on the conducted research, the Ishikawa chart was constructed to identify problematic issues affecting the employment of graduates of the 
EMERCOM of Russia in this ministry. With the help of an expert survey, specific measures were identified to solve this problem.

Because of the conducted research, the stated research goal was fulfilled - a draft "road map" was developed. This project consists of five specific activities with those responsible for their implementation, persons and the expected usefulness for both parties: for students of universities of the EMERCOM of Russia and for the leadership of the ministry. In fact, the developed "road map" can form the basis of a management decision. The practical implementation of this project can bring the solution of the problem of employment of graduates of the EMERCOM of Russia as close as possible.

The research tasks set within the framework of the ongoing work have been completed in full.

\section{References}

1. S.A. Melkov, V.O. Mikryukov, A.Yu. Lyabah, Dolzhen li vypusknik rossiiskogo vuza vladet analiticheskimi navykami? (na primere napravleniya "gosudarstvennoe $i$ munitsipalnoe upravlenie”) [Should a graduate of a Russian university have analytical skills? (on the example of the direction "state and municipal administration")], in Applied scientific research and experimental developments based on the results of fundamental and exploratory research, Conf. Proc. Moscow, 06-07 December. 2016, 145-150. (Publishing house: Plekhanov Russian University of Economics, Moscow, 2017)

2. O.E. Logunova, Primenenie prichinno-sledstvennoj diagrammy Ishikawy $v$ reputacionnom menedzhmente [Application of the Ishikawa causal diagram in reputation management], in Science problems, 1. Proc. I International Scientific and Practical Conference "Scientific research: key problems of the III millennium" Moscow, 30 December, 2015, 54-56. (2015).

3. I.V. Gavrilova, et al., Fund Res, 8, 247-251 (2015)

4. M. Voronin, N. Goryacheva, L. Kokhova, Mod High Tech. Reg App, 3(43), 48-56 (2015)

5. I.A. Sheromova, A.V. Yanchenko, Fund Res, 8(2), 464-469 (2017)

6. I.Z. Aronov, Meth Qual Manag, 8, 18-20 (2012)

7. V. Ilenkova, Diagramma Isikavy: zachem primenyat i kak postroit [Ishikawa Diagram: Why to use and how to build]. Accessed on: October 4, 2021. [Online]. Available: https://pmclub.pro/articles/diagramma-isikavy-zachem-primenyat-i-kak-postroit

8. S. Ivanov, Modeling company sales based on the use of SWOT analysis and Ishikawa charts, in Selected papers of the 8th International conference on monitoring, modeling \& management of emergent economy (M3E2-EEMLPEED 2019), 385-394 (2019)

9. S. Ivanov, SHS Web Conf, 65, 04018 (2019). https://doi.org/10.1051/shsconf/20196504018

10. R. Cahyana, IOP Conf. Series: Mater Sci Eng, 434, 012050 (2018). https://doi.org/10.1088/1757-899X/434/1/012050

11. N.I. Idris, A Case Study of Coffee Sachets Production Defect Analysis Using Pareto Analysis, P-Control Chart and Ishikawa Diagram, in M.S. Bahari, A. Harun, Z. Zainal Abidin, R. Hamidon, S. Zakaria (eds) Intelligent Manufacturing and Mechatronics. 
Lecture Notes in Mechanical Engineering, 1295-1305 (2021).

https://doi.org/10.1007/978-981-16-0866-7_115

12. F. Ikwan, et al. Intelligent Risk Prediction of Storage Tank Leakage Using an Ishikawa Diagram with Probability and Impact Analysis, in K. Arai, S. Kapoor, R. Bhatia (eds) Intelligent Systems and Applications. IntelliSys 2020. Advances in Intelligent Systems and Computing, 1252, 604-616 (2021). https://doi.org/10.1007/978-3-030-55190-2_45

13. G. Ilie, N.C. Carmen, Manag Res Pract, 2(1), 1-20 (2010)

14. M. Suárez-Barraza, F. Rodríguez-González, Int J Qual Serv Sci, 11(2), 302-316 (2017). https://doi.org/10.1108/IJQSS-12-2017-0113

15. Federalnyi zakon "O gosudarstvennoi grazhdanskoi sluzhbe Rossiiskoi Federatsii” ot 27.07.2004 N 79-FZ [Federal Law of the Russian Federation "About the State Civil Service of the Russian Federation" 27.07.2004 No. 79-FZ]. Accessed on: October 4, 2021. [Online]. Available: http://www.consultant.ru/document/cons_doc_LAW_48601/

16. Federalnyi zakon "O sisteme gosudarstvennoi sluzhby Rossiiskoi Federatsii” ot 27.05.2003 N 58-FZ [Federal Law of the Russian Federation "About the civil service system of the Russian Federation" 27.05.2003 No. 58-FZ]. Accessed on: October 4, 2021. [Online]. Available: http://www.consultant.ru/document/cons_doc_LAW_42413/

17. Ukaz Prezidenta RF ot 01.02.2005 N 112 (red. ot 31.12.2020) "O konkurse na zameshchenie vakantnoi dolzhnosti gosudarstvennoi grazhdanskoi sluzhby Rossiiskoi Federatsii" [Decree of the President of the Russian Federation 01.02.2005 No. 112 (ed. 31.12.2020) "About the competition for the vacant position of the state civil service of the Russian Federation"]. Accessed on: October 4, 2021. [Online]. Available: http://www.consultant.ru/document/cons_doc_LAW_51515/

18. Prikaz MChS Rossii ot 05.04.2012 № 174 “'O kvalifikatsionnykh trebovaniyakh k professionalnym znaniyam i navykam, neobkhodimym dlya ispolneniya dolzhnostnykh obyazannostei federalnymi gosudarstvennymi grazhdanskimi sluzhashchimi tsentralnogo apparata i territorialnykh organov Ministerstva Rossiiskoi Federatsii po delam grazhdanskoi oborony, chrezvychainym situatsiyam i likvidatsii posledstvii stikhiinykh bedstvii” (zaregistrirovan v Minyuste Rossii 14.05.2012 № 24140) [Order of the Ministry of Emergency Situations of Russia dated 05.04.2012 No. 174 "On qualification requirements for professional knowledge and skills Necessary for the Performance of Official Duties by Federal State Civil Servants of the Central Office and Territorial Bodies of the Ministry of Civil Defense, Emergencies and Elimination of Consequences of Natural Disasters" (registered with the Ministry of Justice of Russia on 14.05.2012 No. 24140)]. Accessed on: October 4, 2021. [Online]. Available: https://www.mchs.gov.ru/dokumenty/normativnye-pravovye-akty-mchs-rossii/608

19. Report on the employment of graduate students for 2017, 2018, 2019. Internal document of the Center (training and methodological) [text] // Civil Defence Academy of the EMERCOM of Russia, 2021

20. K. Ishikawa, What is Total Quality Control? The Japanese Way. (Prentice Hall, London, 1988) 